\title{
Teaching Short Story through Critical Thinking (CT) Strategies
}

Mukti Prakash Thapaliya

\begin{abstract}
This paper is an attempt to reveal the effectiveness of Critical Thinking (CT) strategies in teaching English literature in general and short stories in particular. Critiquing against the conventional teacher dominated practices in English Language Teaching (ELT) in Nepal, this also offers a set of critical thinking strategies in order to make it more participatory and effective. This heavily draws on my experience of exploiting those techniques while teaching short stories in EFL/ESL classroom in Nepal.
\end{abstract}

Key words: Critical Thinking (CT) Strategies, English as a Foreign Language, Short Story, Anticipation Phase, Building Knowledge Phase, Consolidation Phase (ABC)

\section{Introduction}

The importance of teaching of literature in teaching a language can hardly be exaggerated. In the course of teaching different language skills, various genres of literature are exploited in order to make language teaching more realistic, interesting and effective. Literature is all about human experiences and human reactions to different situations around and students find literary texts more motivating than non-literary ones. Literature is also the storehouse of human experiences, ideas and emotions which both educate and entertain readers. Among various genres of literature, however it is stories which are more captivating than others. It is because stories are everywhere. Everyone has his or her stories to tell. Stories hypnotize readers developing their curiosities about 'what happens next. They have their own importance and recognition.

In language classroom, short stories are used as a means to develop communicative competence (Adhikari, 2006). The study of short stories makes the short stories themselves the content or subject of the course whereas the use of the short stories as a resource draws on short stories as one source among many different kinds of texts for promoting interesting language activities (Lazar, 1993). For our classrooms tend to be usually large-sized, it is not as effective to teach poetry and drama as stories. The poem contains different figures of speech which take more time for them to grasp. Similarly, teaching drama also needs acting which is almost impossible in the classroom due to classroom settingfurniture arrangement, number of students and poor physical infrastructures. Thus, it is easy to teach the short story in our 
classroom for it has well specified and single plot, a small number of characters and an ordinary setting. Several English Language Teaching (ELT) researches reveal that teaching the short story creates enjoyment in the language classroom if the teacher teaches it with appropriate teaching strategies.

Teaching short story has four advantages in the ELT classroom (Pardede, 2011).

- Using short stories are practical as their length is ideally suitable to cover entirely in one or two class sessions.

- Short stories are not complicated for students to work with on their own.

- Short stories have a variety of choices to different interests and tastes.

- Short stories can be used with all levels of English proficiency, all ages and shifts.

However, teaching of stories demand some special techniques to be used in classroom. Unfortunately, observations of trends in teaching in general and English language teaching in particular reveal teacher dominated practices. In the following section, I would like to briefly discuss our conventional practices.

\section{Teaching trends in Nepal}

Studies related to classroom practices have mainly found classroom delivery to have been teacher dominated with an emphasis on rote memorization of the content (CERID, 2004). The dominant approaches used are lecturing, paraphrasing, drill, reading and repeating from textbook, and memorizing questions and answers. In other words, single language, single session, same materials (if used), same method (usually lecture or paraphrasing) were the general practices in classroom delivery. Similarly, CERID's (2002) study had pointed out about $88 \%$ of the teachers (out of 153 observed classes) resorted to the traditional methods of teaching. Singh, Gurung \& Koirala (2010) mention that our classroom teaching learning is mainly focused on content delivery from the textbook. Content delivered by the teachers is either by lecturing or paraphrasing. For paraphrasing either the teacher reads the textbook (few teachers do so) or students are made to read paragraphs from the textbook. Our education system is producing two types of groups, Karkai (2012) stated, one is the teacher who should give the knowledge, but not learning new things, and the second is the student who should take the knowledge but not being creative, active and critical. The above views show the pathetic condition of the teaching learning situations in our classroom teaching.

The teachers of English in Nepal carry out their teaching activities focusing on contents or information only because their main focus is to facilitate learners to become proficient in English, rather than developing higher order of thinking in them (Rana, 2011). Moreover, neither teacher use student-centered methods nor they make the students more active in the classroom. Mostly, teachers use the Grammar Translation Method (GTM), Lecture Method and Paraphrasing Technique inside the classroom while teaching English language. Crowded classrooms, lack of teaching materials, subject teachers, and poor infrastructures are the major problems in the public schools and private 
schools in Nepal.The only way associated with the teaching of literature so far is the Lecture method which is teacher controlled presentation (Dhakal, 2002). Thus, it can be inferred that there is something lacking in our teaching learning activities, which, in turn, induce us to pine for a novel and innovative technique.

The present day world demands us to be critical and analytical. Thus, it is imperative to rethink about our age old classroom teaching learning practices. In this paper, I argue that teaching through Critical Thinking (CT) strategy can be an alternative to fill up this void we have just felt. In the sections that follow, I discuss how critical thinking strategies can be the alternative ways to teach literature in general and short stories in particular.

\section{Critical thinking and its importance}

Critical Thinking (CT) has been interpreted in a number of ways. The commonest element of critical thinking is that it does not take anything as a blind faith. From the time of Socrates to contemporary, concerns about the need for an educated citizenry and quality work-force, the ability to think critically and to reason well has been regarded as an important and necessary outcome of education (Reed, 1998). John Dewey (1933) pointed out that learning to think is the central purpose of education. Schafersman, (1998) defines critical thinking as logical, analytical, reasonable, higher-order, reflective, and scientific thinking as well as reasoning skills. Similarly, Chance (1986) understands critical thinking as the ability to analyze facts, generate and organize ideas, defend opinions, make comparisons, draw inferences, evaluate arguments and solve problems. Whereas Mayer \& Goodchild (1990) describe critical thinking as an active, systematic process of understanding and evaluating arguments, Sternberg (1986) takes it as comprising the mental processes, strategies and representations people use to solve problems, make decisions, and learn new concepts. Scriven, \& Paul, (2012) gives a very comprehensive interpretation of the term and according to him, critical thinking is the intellectually disciplined process of actively and skillfully conceptualizing, applying, analyzing, synthesizing, and/ or evaluating information gathered from, or generated by observation, experience, reflection, reasoning, or communication as a guide to belief and action. Similarly, Ennis (1989) defines critical thinking as a reasonable, reflective thinking that is focused on deciding what to believe or do. Critical thinking means ability to judge anything from different angles. For Lohani, Adhikari \& Subedi (1998) critical thinking refers to consciously observing, analyzing, reasoning, and evaluating, according to proven standards. It can be understood in terms of six cognitive skills: interpretation, analysis, evaluation, inference, explanation and self-regulation (Facione, 2007).

To sum up the above viewpoints, we can say that critical thinking is a process of actively and skillfully conceptualizing, applying, and evaluating arguments which does not take anything for granted.

The advantages of critical thinking in teaching are many. Critical Thinking encourages teachers to facilitate students to create knowledge by questioning, examining, analyzing, and evaluating rather than by memorization. It allows 
students to develop their potentials by letting them learn at their own pace. According to Crawford, Saul, Mathews and Makinster (2005), teachers should support reading and writing for critical thinking in classroom. They should challenge their students not just to memorize but to question, examine, create, solve, interpret and debate the material in their courses. Moreover, its different instructional methods help students to be more reflective, creative, and analytical.

The importance of critical thinking can be seen in its role in promoting effective planning, reflection, action and learning. Crawford, Saul, Mathews \& Makinster (2005) have mentioned the importance of Critical Thinking (CT) which are:

- Critical Thinking helps us interpret information such as the ability to critically analyze, recognize misinformation and become active citizens.

- It assists us in making better decisions about our actions.

- it encourages us to think about our own prejudices.

- it challenges prevailing social, political, cultural and technical ways of thinking.

- it encourages us to go beyond rationality, using our creativity to go outside the traditional boxes of knowledge and understanding.

- $\quad$ it helps us criticize, reject or adapt tools and methods which makes us more responsible this towards our classroom.

\section{Critically thinking phases}

Having established the importance of critical thinking in teaching, I would like to discuss the critical thinking phases that a teacher can divide his/her instructional activities into. In fact these are the steps to be followed by the teachers while making lesson in order to develop critical thinking strategies. Crawford, Saul, Mathews \& Makinster (2005) have mentioned that CT lesson has three phases namely anticipation, building knowledge and Consolidation.

\section{Anticipation phase:}

In the anticipation phase, students are directed to think and ask questions about the topic they are about to study. It serves to call up the knowledge that students already have learned. Moreover, it sets purposes for learning and provides a context for understanding new ideas which is similar to Pre- teaching stage. Some strategies used in this phase are: What do we know?, structured overview, brainstorming, paired-brainstorming, semantic- map, predictions from terms, think-pair-share $(\mathrm{T} / \mathrm{P} / \mathrm{S}), \mathrm{mix} / \mathrm{freeze} / \mathrm{pair}$, pens in the middle, walk around-talk around, spider web and so on.

\section{Building knowledge phase:}

The building knowledge phase serves to compare expectations with what is being learned. In this stage, student identifies the main points and makes the personal connections to the lesson which is similar to while teaching stage. Pair-reading, pair-summarizing, so what?, what do we want to learn?, brainstorming, pairedbrainstorming, directed reading activity (DRA), directed reading thinking activity (DRTA), reading with text coding, pens in the middle, reciprocal teaching, one stay/ three stray, directed listening-thinking 
activity etc. are some of the strategies used in this phase.

\section{The consolidation phase:}

This phase occurs toward the end of the lesson in which teachers expect students to reflect on what they learned, ask what it means to them, reflect on how it changes what they thought, and ponder over how they can use it, which is similar to Post teaching stage. In this phase, we can use the strategies such as, what did we learn?, value line, quick-write, now-what?, charactermap, think-pair-share (T/P/S), jgsaw, pens in the middle, walk around- talk around, debates etc.

\section{Critically thinking strategies in teaching short stories}

There are various Critical Thinking strategies applied in teaching in different situations and contexts. Teacher can employ various critical thinking strategies in order to make students think critically. According to Crawford, Saul, Mathews \& Makinster, 2005, Critical Thinking Strategies are:

\section{Know/want to know/ learn (K-W-L)}

The K-W-L activity can be used to structure a whole lesson. It asks students to think of what they already know about the topic of the lesson, raise questions about it, and find answers to those questions. We can use this strategy in any class comprising to 6-60 students. We should select the topic and create a K-W-L chart on the chalk board or on the chart. It can be used to ask about what student already know about the story/topic/title. In the similar way, we can use it to ask questions and confirm their knowledge. It can be useful in any phase in while teaching any literary text including short stories. For instance,

Teacher begins by naming the topic, and asking students to think of what they already know about it which helps to have students list their ideas, and to share their ideas with a partner before they answer. After that, the teacher draws/makes a K-W-L chart on the white board or on the chart paper like this.

\begin{tabular}{|l|c|l|}
\hline What do we Know? & $\begin{array}{c}\text { What do we Want } \\
\text { to Know? }\end{array}$ & What did we Learn? \\
\hline & & \\
\hline
\end{tabular}

Then, he/she asks the students to call out what they know about the topic and he/she writes their ideas in What do we know? column. After that, he/she asks the students to think of questions they have about the topic. They may begin by reviewing what they know, and finding where their knowledge is incomplete and write their questions on the What do we Want to Know? column. They should read the story/ passage/text and they are reminded to look for answers to their questions. What they learned from the text can be written in the What did We Learn? column.

\section{Directed reading activity (DRA)}

DRA strategy is designed to support students' reading comprehension by guiding them to key points in the text and providing opportunities to discuss its meaning with their classmates. Before implementing DRA, the teacher should chunk the text by dividing it into manageable pieces for the students to read silently. Then, the teacher should prepare one or two comprehensionlevel questions for each chunk to be read by the students. In this strategy, students may Think-Pair and Share their ideas with the group or whole class. This strategy is useful for teaching narrative texts. 
Think-Pair-Share (T/P/S)

Think-Pair-Share is a strategy for having students think of individual answers to a question posed by the teacher, and then share their answers with a partner. Later, the teacher calls on two or three pairs to share their answers with the whole class. It can be used in the anticipation, building knowledge and consolidation phase.

\section{Structured Overview}

Ausubel (1968) developed structured overview. A brief lecture is given to arouse students' curiosity at the beginning of a lesson in structured overview. After that, teacher will make a list of vocabularies, maps, or bring real objects which arouse students' interest. Then, teacher will make short talk with students that will reflect the key points. It is used in the beginning of the class which helps to motivate students towards the lesson. It is used in the anticipation phase.

Pair -Reading and Pair-Summarizing (PR-PS)

The teacher chooses a text of reasonable length which should have short paragraphs. After that, read a passage aloud and give a summary of it. In PR-PS, one student reads the text, next one summarizes it. If he/ she cannot understand the text, the reader explains and tries to make it clear. PR/PS is used in the building knowledge phase which can be used especially while teaching short stories and essays.

Mix/Freeze/Pair:

In thisstrategy, the teacher gives instructions in the classroom and students follow it which is very good to develop social skills, work cooperatively and make them more alert. The teacher gives them signal to stop and move/walk in the classroom when he/ she says freeze they should stop and make pair with the person who is close to them. It is used in the anticipation phase to arouse students' curiosity towards the lesson.

\section{What? So what? Now what?}

In this strategy, the teacher selects the topic which students know then he/she discusses with it among the students. After that he/ she divides the whole lesson into three subtopics such as:

\begin{tabular}{|l|l|l|}
\hline \multicolumn{1}{|c|}{ What? } & \multicolumn{1}{|c|}{ So What? } & Now What? \\
\hline Anticipation & Building knowledge & Consolidation \\
\hline
\end{tabular}

In What? Column, the teacher asks the students to summarize the most important ideas they have just discussed about the topic. In So what? Column, students write the important idea they have just listed. At last, in Now What? Column, the teacher asks what they can do about the problem they have been discussing. Moreover, it is similar with $\mathrm{ABC}$ phases. We can use it while teaching stories. Particularly, while teaching supernatural stories, this technique can be very effective.

8. Semantic Map: In this strategy, the teacher makes a semantic map on the blackboard that helps to teach difficult vocabulary, show relation between different characters and and many other things. For example,

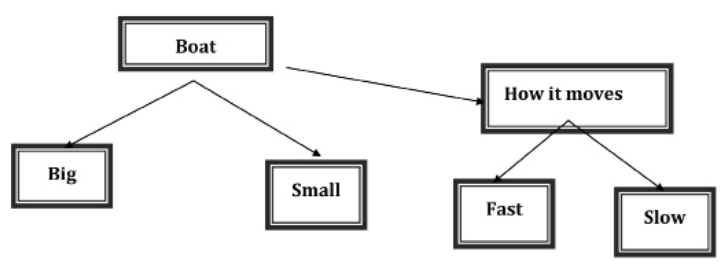

Prediction from terms:

In this strategy, the teacher selects five or six words or phrases from the text and 
writes these on the blackboard. After that, the teacher tells them to write/ compose a story or poem or song or essay or picture or drama by using these words. Such as,

compose a poem or story or drama or song by using the following words in your own words. Old man, soldier, detention centre, Aswi, Moist etc.

\section{Pens in the middle:}

'Pens in the Middle' strategy is intended to ensure that all students have the opportunity to participate in learning group, and provide the teacher with a stimulus for asking students about their contributions. When students begin to share ideas in the typical learning group of 3-7 members, each student marks his or her contribution by placing a pen on the table in the middle of the group. It can be used in $\mathrm{ABC}$ phases especially while teaching short stories and writing skill i.e. free and guided writing.

\section{Cooperative learning:}

It may work more efficiently if students are assigned certain roles within the groups. The roles may rotate among the group members, though, so each student will have plenty of opportunities to practise each role. It is basically intended to give each student a clearly understood contribution to make to the success of the group; and to teach each student, over time, the skills and attitudes that make a cooperative and productive group member. It is used in the building knowledge phase while teaching literary text.

\section{Close Reading with Text Coding}

It refers to the act of having students look for certain things in a text, then mark the text when those things are found with a simple symbol for each kind. In close reading with text coding strategy, the teacher thinks four or five kinds of information which students can locate in a text. After that, he/ she explains to the students the kinds of information which you want them to look for as they read the text. He/she tells the students to begin reading the assigned text and to mark each piece of information of each type.

\section{Value line}

It is a cooperative learning activity that is recommended for evoking students' opinions on issues to which there can be varied responses. In other words, it is an activity that requires students to take a position on an issue and to support it with reasons. The teacher begins by posing a polarizing questions such as, is war good for human being? It is useful for students to stand up for their beliefs even when friends disagree. It can be very effective while teaching supernatural stories.

\section{Using Critical Thinking (CT) Strategies while teaching "I Heard Cock Crow"}

I endeavored to apply Critical Thinking (CT) strategies while teaching English language and literature after I first did a course on Critical Thinking in 2009. I have been using most of the techniques discussed above and they have been extremely motivating and effective too. I think we need to teach our students that reading involves not simply gaining information, but actively seeking a deep understanding of the meaning, applications of that information. Particularly, short stories have a unique potential to stimulate thought, generate emotions and spark the imagination. However, a worker always 
needs tools, even when dealing with the best of materials, and this holds true when working with a short story.

While I taught a story "I Heard Cock Crow" from the textbook 'New Generation English' prescribed for B. Ed. First year students, it is true that I spent more time planning my lesson(Please see lesson plan in appendix), arranging the sitting plan i.e. bench, than conventional teaching because I wanted to make students more responsible and active for learning in the classroom. I changed the conventional classroom sitting into " $U$ " shape so that students can easily take part in learning activities. Then I talked about war and its effects which aroused students' curiosity and their attention could be focused on the present story. After that, I wrote six words from the story such as, war, Aswi, Martin, old boatman, ethnic riot, delegation, young man \& woman. I asked them to use the above words and compose anything as they like such as a poem, a story, an essay and so on. Then, I divided the students into pair. I gave them 2-3 minutes to share their creations with their pair. I asked two pairs of the classroom to share their answer with the classroom. I asked them, "Can you guess what chapter we are going to read, today?" Students answered that I Heard Cock Crow. After that, I wrote the title of the story "I Heard Cock Crow" on the board and pasted a chart on the wall which contained three columns such as Know-Want to Know - Want to Learn. After that I wrote the title and author's name on the board and questions on the chart paper such as, Do you notice anything unusual about the title of the story?, Can you guess what the story is about, based on the following key words: war, Aswi, Martin, old boatman, ethnic riot, delegation, young man \& woman? I found students were enthusiastic about this last question as they always are when asked to guess. Using their imagination, they supplied various answers.

I divided the story into the five sections where I used DRA strategy. Students read the text and answered the questions I had set. The students took part actively in the discussion. If there was any confusion, I made it clear for them. Ialso introduced pairreading and Pair-Summarizing strategies which made the class more interesting and lively. I used value line and quick-write strategies in the consolidation phase. I found students participated actively in the value line strategy. I put various thought provoking questions beyond the reading text and they shared their own perspectives. Finally, when I asked: "How is the today's class?" most of the students said that it was really interesting class because they could remember things. Besides the fun activities, the students said they enjoyed because the activities demanded them to be active and think on issues instead of depending upon teachers for answers while taught in conventional ways. Even the students who had never taken part in any activities take part in the classroom activities. This success has reshaped my teaching of language and literature considerably.

\section{Conclusion}

Teaching English language helps students to communicate and write fluently in the target language. There are different classroom techniques that teachers use. Among them, critical thinking (CT) strategy is comparatively a new one 
in Nepal but it has been employed in twenty nine countries including United States, Canada, the United Kingdom and Australia (Crawford, Saul, Mathews \& Makinster, 2005) which can make students more creative, active, innovative, critical, analytical and constructive because its' strategies are based on student-centered which enhance active learning. It does not mean that all CT strategies are appropriate in our context. The geography, economic status of institutions, physical infrastructures such as, not having well ventilated classroom, sufficient furniture, library etc, cause difficult in using the different critical thinking strategies. Likewise, school administration has been a big stumbling block in giving teachers autonomy. They are found to compel teachers to use conventional techniques in their classroom instead of using latest methods and strategies in their classroom teaching which are likely to pose some problems from administration and management point of views. Most ELT practices are teacher dominated because they have still been using Grammar Translation and Audio-lingual methods of language teachings. It is high time we practiced critical thinking strategies in ELT to make it more student centered. Experiences have revealed that teaching of literature in general and teaching of short stories in particular can be made immensely effective if CT strategies are used. However, the selection of the CT strategies should be done according to the course objective, students proficiency level and teaching learning material.

\section{About the author}

Mukti Prakash Thapaliya holds Master's Degree in English Education from Tribhuvan University. He has been teaching English Language and Literature at Bachelor's and Master's levels at Gramin Adarsha Multiple Campus, Nepaltar, Balaju, Kathmandu, Nepal, for last seven years.

He has presented papers on Language Teaching and Critical Thinking (CT) Strategies in different seminars and trainings, and has also published his articles in different journals. He is a life member of Nepal Language English Teachers' Association (NELTA) and Master Trainer of Critical Thinking (CT) Strategies. His areas of interest include English Language teaching and Inclusive Education.

\section{References}

Adhikari, B.(2006). Teaching Short Stories. Journal of NELTA, 11, 1-2, Pp. 108-110.

Bhandari \& Gyawali, (2000). Teaching English Literature. Kathmandu:Ashish Pustak Bhandar.

CERID. (2002). Effective Classroom Teaching Learning (Phase 1: Classroom Delivery). Kathmandu: CERID

CERID. (2004). Access of Muslim Children to Education (Phase II). FRP for BPEP, Kathmandu: CERID.

CERID. (2005). Access of Disadvantaged Children to Education. FRP for BPEP, Kathmandu: FRP for BPEP. Kathmandu: CERID.

Chance, P. (1986). Thinking in the classroom: A survey of programs. New York: Teachers College, Columbia University.

Crawford, A., Saul, E.W., Mathews, S. and Makinster, J. (2005).Teaching and Learning Strategies for the Thinking Classroom. Kathmandu: Alliance for Social Dialogue.

Dhakal, D.N. ,(2002). The Techniques of Teaching Literature. Journal of NELTA, 7, 1-2. , Pp. 90-95.

Karkai, B. ,(2012). Where is lacking our Learning? The Kantipur Daily: Kathmandu.

Lazar, G.(1993). Literature and language teaching. Cambridge: CUP.

Lohini, S., Adhikar, R. \& Subedi, A. (1996). The magic of words. Kathmandu: M.K. Distributor.

Mayer, R. E., \& Goodchild, F. M. (1990). The critical thinker: thinking and learning strategies for psychology students. Dubuque, IA: WM.C. Brown.

Pardede, P. (2011). Using short stories to teach 
language skills. Journal of English Teaching, 1, 1, Pp. 15-27.

Reed, J.(1998). Effect of a model for critical thinking on student achievement in primary source document analysis and interpretation, argumentative reasoning, critical thinking dispositions, and history content in a community college history course. Unpublished Ph.D. dissertation, University of South Florida, USA

Schafersman, S. D.(2012). Critical thinking and its relation to science and humanism. Retrieved in 2012, July, from:http://cybercomputing.com/ freeinquiry/files/critical-notes.html.

Scriven M., \& Paul, R.(2012). Defining critical thinking. The critical thinking community: Foundation for critical thinking. Retrieved in 2012, July,fromhttp://www.criticalddnking.org/ aboutCT/ define_criticat_thinking.cfm. (2007).
Sharma, H.M. (2006). Ways of Effective Language Teaching in Heterogeneous Class. Journal of NELTA, 11, 1-2, pp. 115-119.

Singh, G., Gurung, I. and Koirala, S. (2010). Baseline study on existing classroom teaching learning practices in Nepal. Kathmandu: Alliance for Social Dialogue.

Sternberg, R. J. (1986). Critical thinking: Its nature, measurement, and improvement. Washington DC: National Institute of Education.

Tully, M. M. (2009). Mind mirror projects: a tool for integrating critical thinking into the English language classroom. English Teaching Forum. 47, 1, pp. 10-17.

Zabeli, N. and Saqipi, B.(2008). Interactive teaching strategies reduce inappropriate student Behavior in Kosovo. Journal of Thinking Classroom, 9, 1, Pp. 6-10. 


\section{Appendix \\ Lesson Plan based on CT strategies}

Subject: Com. English

Time: 50 Min.

\author{
Class: B.Ed. $1^{\text {st }}$ year
}

College: GAMC

Date: 10 ${ }^{\text {th }}$ May, 2011

\begin{tabular}{|c|c|}
\hline Lesson Objectives & $\begin{array}{l}\text { At the end of this lesson, students will be able to : } \\
\text { - } \quad \text { summarize the four paragraphs of the story in their own words } \\
\text { - } \quad \text { argue how wars have brought destruction and sufferings in Nepal } \\
\text { - write an argumentative essay on 'war is never good' in } 150 \text { words }\end{array}$ \\
\hline Teaching Materials & $\begin{array}{l}\text { Daily use materials, Chart Paper, Masking tape, markers, New Generation English Page no. 107'I heard cock crow' - Amod } \\
\text { Bhattarai }\end{array}$ \\
\hline Teaching Learning Activities & Stages \\
\hline $\begin{array}{l}\text { Anticipation Phase (10 Minutes) } \\
\text { Strategies : Structured overview, } \\
\text { Predicting from Terms, T/P/S, K-W-L }\end{array}$ & $\begin{array}{l}\text { - } \text { change the classroom sitting into U shape } \\
\text { - } \quad \text { gives short introduction of war and its effect } \\
\text { - } \quad \text { divides the class into different groups, pair and individual } \\
\text { - } \quad \text { select 5- } 8 \text { vocabulary from the text that point to key concepts from the text such as war, Aswi, Martin, old boatman, } \\
\text { - } \text { ethnic riot, delegation, young man, woman } \\
\text { - } \quad \text { paste the chart paper which contains Know/Want to Know/ Learn (K-W-L) } \\
\text { - } \quad \text { invites a few pairs to share their imagined stories } \\
\text { - } \quad \text { requests them to listen carefully to what the teacher is about to tell and see how it compares with what they imagined } \\
\text { - } \quad \text { writes the title of the story on the white board and explains it }\end{array}$ \\
\hline $\begin{array}{l}\text { Building Knowledge Phase (30-35Min- } \\
\text { utes) } \\
\text { Strategies: } \\
\text { DRA } \\
\text { Paired reading \& summarizing }\end{array}$ & $\begin{array}{l}\text { - } \quad \text { makes /gives a short introduction about the story, writer } \\
\text { - } \quad \text { asks students to read the first } 5 \text { lines of the story silently and summarize it } \\
\text { - } \quad \text { ask and writes the question on the board such as "Do you think the setting of the story is Nepal? How can you prove } \\
\text { - } \quad \text { asks to read the } 6 \text { - } 11 \text { lines and answer the question such as "Peace is essential element of development." Justify and } \\
\text { - } \quad \text { what is your summary? } \\
\text { - } \quad \text { asks some pairs and groups to share their answer and suggests to guess what will happen next } \\
\text { - } \quad \text { and what is your summary? } \\
\text { - } \quad \text { tells the main points or summary of the } 1-20 \text { lines of the story orally } \\
\text { - } \quad \text { teacher writes questions and answers on the chart paper/ white board }\end{array}$ \\
\hline $\begin{array}{l}\text { Consolidation Phase (10-15 Minutes) } \\
\text { Strategies: T/P/S, value line, Quick- } \\
\text { reading and Quick- writing }\end{array}$ & $\begin{array}{l}\text { - } \text { each group works on 1-20 lines of the story and extract all war related vocabulary } \\
\text { - } \quad \text { read aloud the list of the war related vocabulary in group } \\
\text { - } \quad \text { make their own sentence by using those words } \\
\text { - } \quad \text { teacher writes those words on the white board } \\
\text { - } \text { divides students into three groups such as war is good (Group A), war is never good (Group B) and neutral (Group C) } \\
\text { - } \quad \text { each group justifies their views to attract the neutral group members to come in their group } \\
\text { - } \text { assigns students to write an essay on harms caused by war in Nepal. } \\
\text { assigns students to argue for or against the motion 'war is never good'. }\end{array}$ \\
\hline
\end{tabular}

